\title{
Total oxidant status, total antioxidant status, and paraoxonase activity in acute appendicitis
}

\author{
Hande Köksal, M.D., ${ }^{1}$ Sevil Kurban, M.D., ${ }^{2}$ Osman Doğru, M.D. ${ }^{1}$ \\ ${ }^{1}$ Department of General Surgery, Konya Training and Research Hospital, Konya; \\ ${ }^{2}$ Department of Biochemistry, Necmettin Erbakan University Meram Faculty of Medicine, Konya
}

\begin{abstract}
BACKGROUND: The aim of this study was to investigate the levels of oxidative stress including total oxidant status, total antioxidant status, and paraoxonase activity in patients with a diagnosis of acute appendicitis.

METHODS: Seventy-three patients who underwent surgery with a preoperative diagnosis of acute appendicitis (Group I) were included into the study. The control group (Group II) consisted of thirty otherwise healthy subjects. After histopathologic examination, the patients were categorized as follows: I) Acute focal appendicitis, 2) Acute advanced appendicitis including acute suppurative, phlegmonous and gangrenous appendicitis, 3) Acute perforated appendicitis, 4) Sub-acute appendicitis, and 5) Negative exploration. Blood samples for paraoxonase activities, and total oxidant and antioxidant status levels were obtained preoperatively.
\end{abstract}

RESULTS: Total oxidant and antioxidant status of the patients in the acute appendicitis group were higher than those of the control group. When paraoxonase activities of Group I was compared with Group II, no significant difference was determined. Both total oxidant and antioxidant status levels of acute perforated appendicitis were higher than those of both acute focal appendicitis and acute advanced appendicitis.

CONCLUSION: The increase in the oxidative status (total oxidant and antioxidant status) was related with the progression of inflammation to the perforation in acute appendicitis.

Key words: Acute appendicitis; paraoxonase activity; total antioxidant status; total oxidant status.

\section{INTRODUCTION}

Acute appendicitis (AA), a common and urgent surgical illness, is a condition characterized by the inflammation of the appendix. It is thought to result from obstruction of the appendiceal lumen, typically by lymphoid hyperplasia, but occasionally by a fecalith, foreign body, or even worms. The obstruction leads to distention, inflammation, bacterial overgrowth, and finally ischemia. If untreated, necrosis and perforation occur. If the perforation is restricted by the omentum, an appendiceal abscess develops. ${ }^{[1]}$

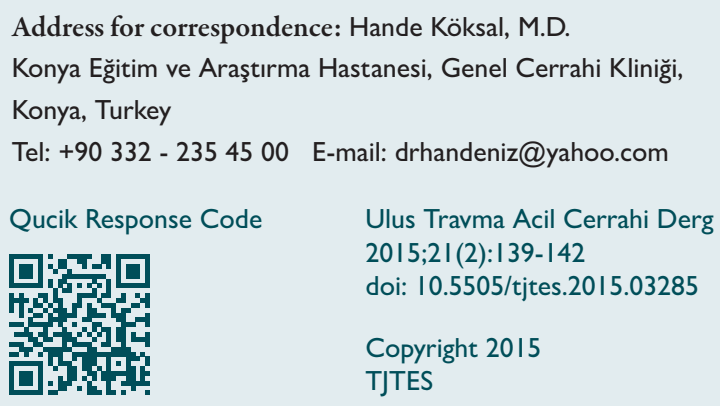

Paraoxonase (PONI) is associated with high-density lipoprotein particles and is known to have an antioxidant function. In humans, the PON gene family has three members, PONI, PON2, and PON3. PONI has three known enzymatic molecules, including PON, arylesterase (ARE) and dyazoxonase. Human serum PONI and ARE are both esterase enzymes that have lipophilic antioxidant characteristics. These enzymes play a role in decreasing oxidative stress. PONI, in particular, is an important endogenous free radical scavenging system in the human body. ${ }^{[2-5]}$

Studies of oxidative stress in AA have been reported until today. ${ }^{[6-9]}$

The aim of this study was to investigate the levels of oxidative stress including total oxidant status, total antioxidant status, and paraoxonase activity in patients with a diagnosis of AA.

\section{MATERIALS AND METHODS}

Seventy-three patients who underwent surgery with a preoperative diagnosis of acute appendicitis (Group I) were included into the study. The control group (Group II) consisted 
of thirty otherwise healthy subjects. The presence of any of the following conditions was used as an exclusion criteria in this study: diabetes mellitus, neoplastic disease, inflammatory disease (such as infections and autoimmune disorders), hypercholesterolemia, hypertriglyceridemia, use of an antihypertensive medication, lipid-lowering drug use, antioxidant substance use, known secondary hypertension, chronic renal failure, cerebrovascular disease, ischemic heart disease, congestive heart failure, gastrointestinal disease or liver disease. The demographic features, complete blood count and final pathologic diagnosis of the patients were recorded. Leukocyte counts greater than $10 \times 10^{9} / \mathrm{L}$ was defined as leukocytosis. Neutrophil rate greater than $74 \%$ was defined as neutrophilia.

After histopathologic examination, the patients were categorized as follows: I) Acute focal appendicitis (AFA), 2) Acute advanced appendicitis (AAA) including acute suppurative, phlegmonous and gangrenous appendicitis, 3) Acute perforated appendicitis (APA), 4) Sub-acute appendicitis (SA) and 5) Negative exploration.

Blood samples were obtained preoperatively. Serum samples were centrifuged for $15 \mathrm{~min}$ at $3000 \mathrm{rpm}$, transferred to Eppendorf tubes and stored at $-80^{\circ} \mathrm{C}$, and were used to measure TAS and TOS levels, and paraoxonase activity.

Paraoxonase activity was measured by using paraoxon and phenylacetate as substrates. The basal activity of paraoxonase was measured. The rate of paraoxon hydrolysis (diethyl-p-nitrophenylphosphate) was measured monitoring an increase in absorbance at $412 \mathrm{~nm}$ at $37^{\circ} \mathrm{C}$ on an autoanalyser (Beckman Coulter, Fullerton, CA, U.S.A.). The amount of generated pnitrophenyl was calculated from the molar absorptivity coefficient at a $\mathrm{pH}$ of 8.5 , which was $18290 \mathrm{M}^{-1} \mathrm{~cm}^{-1} .{ }^{[0]}$ Paraoxonase activity was expressed as $U / L$ of serum.

TAS levels of the sera were determined using an automated measurement method based on bleaching of the characteristic color of a more s 2,2'-azino-bis [3-ethylbenz-thiazoline6-sulfonic acid (ABTS)] radical cation caused by antioxidants. [II] The results were expressed in mmol Trolox equivalents/L.

TOS levels of the sera were determined using a novel automated measurement method. ${ }^{[12]}$ Oxidants present in the sample oxidized the ferrous ion-o-dianisidine complexes into ferric ions. The oxidation reaction was enhanced by glycerol molecules that were abundantly present in the reaction medium. The ferric ions formed a colored complex with xylenol orange in an acidic medium. Therefore, color intensity, measured spectrophotometrically, was related to the total number of oxidant molecules present in the sample. The assay was calibrated with hydrogen peroxide and the results were expressed in terms of micromolar hydrogen peroxide equivalent per liter ( $\mu \mathrm{mol} \mathrm{H}_{2} \mathrm{O}_{2}$ equiv./L).

The study protocol was approved by the Ethics Committee of Selcuk University, Faculty of Medicine (number 20l0/I3), and was conducted according to the Declaration of Helsinki, Good Clinical Practice Guidelines. The participants were informed about the nature of the study and informed consents were obtained.

Statistical analysis was performed using SPSS software for Windows, release 13.0. Results were expressed as mean \pm standard deviation (SD). Statistical analysis was performed using the Mann-Whitney $U$ test, and statistical significance was assumed at a level of $p<0.05$.

\section{RESULTS}

Seventy-three patients who underwent surgery with a diagnosis of acute appendicitis and thirty healthy subjects were included into the study. In Group I, the median age of the patients was 24 years (range, 16-60 years), and thirty-seven of the patients were male and thirty-six patients were female. In Group II, the median age was 25 years (range, 16-48 years), and seventeen of the patients were female and thirteen were male.

Mean and SD values of TOS and TAS levels, and PONI activities are presented in Table I. TOS and TAS levels of the patients were higher than the ones of the control groups $(p=0.000 \mathrm{I}$ and $p=0.004$, respectively). When PONI activities of Group I were compared with Group II, no significant difference was determined.

TOS, and TAS levels, and PONI activities of the patients were analyzed according to leukocyte counts, neutrophil rates, duration of symptoms, and pathologic subgroups (Table 2).

Table I. Total oxidant status, total antioxidant status levels, and paraoxonase activity of the patients and control groups

\begin{tabular}{lccc}
\hline & Group I* & Group 2 & p \\
\hline TOS $\left(\mu \mathrm{mol} \mathrm{H} \mathrm{O}_{2}\right.$ equiv./L) & $44.45 \pm 29.55$ & $22.34 \pm 7.04$ & 0.000 I \\
TAS $(\mathrm{mmol}$ Trolox equivalents/L) & $2,49 \pm 0,56$ & $2,21 \pm 0,32$ & 0.004 \\
PONI $(\mathrm{U} / \mathrm{L})$ & $51.96 \pm 39.15$ & $55.97 \pm 36.91$ & 0.63 \\
\hline The patients with negative exploration were excluded because definitive pathologic diagnosis was not appendicitis.
\end{tabular}


Table 2. TOS and TAS levels and PONI activities according to the subgroups of the patients

\begin{tabular}{|c|c|c|c|}
\hline & TOS & TAS & PONI \\
\hline \multicolumn{4}{|l|}{ *Leukocyte counts } \\
\hline Normal $(n=12)$ & $58.49 \pm 49.06$ & $2.6 \pm 0.92$ & $48.92 \pm 46.46$ \\
\hline Leukocytosis $(n=56)$ & $39.59 \pm 21.63$ & $2.4 \pm 0.44$ & $54.04 \pm 36.72$ \\
\hline$P$ value & NS & NS & NS \\
\hline \multicolumn{4}{|l|}{ *Neutrophil rate } \\
\hline$\leq 74 \%(n=24)$ & $50.63 \pm 39.82$ & $2.52 \pm 0.72$ & $55.72 \pm 37.93$ \\
\hline$>74 \%(n=44)$ & $38.72 \pm 19.91$ & $2.43 \pm 0.42$ & $51.68 \pm 38.8$ \\
\hline$P$ value & NS & NS & NS \\
\hline \multicolumn{4}{|l|}{ *Duration of the symptoms } \\
\hline$\leq 24$ hours $(n=18)$ & $52.51 \pm 43.34$ & $2.6 \pm 0.78$ & $57.3 \pm 38.21$ \\
\hline $24-48$ hours $(n=23)$ & $35.7 I \pm 17.84$ & $2.37 \pm 0.46$ & $54.69 \pm 44.95$ \\
\hline$>48$ hours $(n=27)$ & $42.68 \pm 21.16$ & $2.45 \pm 0.42$ & $49.07 \pm 30.95$ \\
\hline$P$ value & NS & NS & NS \\
\hline \multicolumn{4}{|l|}{ Patologic subgroups } \\
\hline AFA $(n=38)$ & $39.65 \pm 20.27$ & $2.45 \pm 0.43$ & $51.03 \pm 41.03$ \\
\hline $\operatorname{AAA}(n=19)$ & $38.76 \pm 20.6$ & $2.35 \pm 0.43$ & $57.1 \pm 39.17$ \\
\hline APA $(n=5)$ & $102.52 \pm 54.96$ & $3.35 \pm 1.13$ & $39.27 \pm 24.51$ \\
\hline SA $(n=6)$ & $27.21 \pm 12.86$ & $2.18 \pm 0.13$ & $65.04 \pm 28.1$ \\
\hline Negative exploration $(n=5)$ & $28.06 \pm 3.25$ & $2.43 \pm 0.52$ & $81.45 \pm 6.01$ \\
\hline$P$ value & $\dagger$ & $\ddagger$ & $t \dagger$ \\
\hline \multicolumn{4}{|c|}{$\begin{array}{l}\text { ": The patients with negative exploration were excluded because definitive pathologic diagnosis was not appendicit } \\
\because \text { : AFA vs APA, } p=0.007 ; \text { AAA vs APA, } p=0.009 ; \text { SA vs APA, } p=0.028 ; \text { Negative exploration vs AFA, ASA and AF } \\
(p=0.003, p=0.039 \text { and } p=0.016, \text { respectively). } \\
\neq: \text { AFA vs APA, } p=0.049 ; \text { AAA vs APA, } p=0.025 \text {. } \\
\text { I: Negative exploration vs AFA, ASA and APA ( } p=0.0001, p=0.017 \text { and } p=0.016 \text {, respectively). }\end{array}$} \\
\hline
\end{tabular}

ized by necrosis and destruction of the appendix. ${ }^{[14,15]}$

Oxidative stress is essentially an imbalance between the production of free radicals and the ability of the body to counteract or detoxify their harmful effects through neutralization by antioxidants. It leads to many pathophysiological conditions including neurodegenerative diseases, cancers, heart and blood vessel disorders, and inflammatory diseases. The immune system uses lethal effects of oxidants by making production of oxidizing species a central part of its mechanism of killing pathogens, with activated phagocytes producing both reactive oxygen species and reactive nitrogen species, including superoxide, nitric oxide, and their particularly reactive product, peroxynitrite. Although the use of these highly reactive compounds in the cytotoxic response of phagocytes causes damage to host tissues, the nonspecificity of these oxidants is also an advantage since they will damage almost every part of target cell. This prevents the pathogen escaping from immune response by mutation of a single molecular target. ${ }^{[2-5]}$

\section{DISCUSSION}

Acute appendicitis, a condition caused by the inflammation of appendix, is a common and urgent surgical illness with many manifestations, generous overlaps with other clinical syndromes, and significant morbidity increasing with diagnostic delay. No single sign, symptom, or diagnostic test accurately confirms the diagnosis of appendiceal inflammation in all cases. In pathophysiology of AA, obstruction of the appendiceal lumen by thick mucus, feces, a foreign object, or sometimes even a tumor is the primary cause of appendicitis. An anatomic blind pouch or obstruction of the appendiceal lumen leads to distension of the appendix due to accumulated intraluminal fluid. Ineffective lymphatic and venous drainage allow bacterial invasion of the appendiceal wall and, in advanced cases, perforation and spillage of pus into the peritoneal cavity can be seen. ${ }^{[1,13]}$

On pathology, the following stages of AA can be distinguished: I) simple appendicitis where the inflamed appendix is still viable; 2) gangrenous appendicitis is characterized by focal and diffuse necrosis; and 3 ) perforated appendicitis is character-
Several studies on oxidative stress in AA have been reported up to now. ${ }^{[6-9]}$ In a study by Koltuksuz et al., ${ }^{[6]}$ plasma superoxide dismutase activity and malondialdehyde level in AA have been studied. In this study, both superoxide dismutase and malondialdehyde have been significantly higher in both acute suppurative and perforated appendicitis than both control and AFA. They have speculated that oxygen free radicals may play an important role in the extent of AA. In another study by Ozdogan et al.," ${ }^{[7]}$ the levels of TAS and malondialdehyde levels in patients with acute phlegmonous appendicitis, advanced appendicitis or negative exploration have been investigated. In patients with AAA (acute gangrenous or perforated appendicitis), TAS level has been significantly lower than the other groups, and they have concluded that TAS might be a predictor for the progression of inflammation to the perforation in AA. Total antioxidant capacity in children with AA has been investigated, and total antioxidant capacity level in AA has been significantly higher than non-appendicitis and healthy groups in another study by Kaya et al. ${ }^{[8]}$ The possible role of nitric oxide and whether there is a relation between oxidative stress and nitric oxide in AA has been investigated in another study. ${ }^{[9]}$ It has been found that serum nitric oxide 
levels and oxidative stress elevate in AA independently from the extent of pathology, and the authors have concluded that increased nitric oxide could play a role in the increased oxidative stress levels in AA.

PONI has many enzymatic activities and is known to have an antioxidant function. These enzymes play a role in decreasing the oxidative stress. PONI in particular is an important endogenous free radical scavenging system in the human body. Decreased PONI activity has been observed in patients with different diseases, including coronary artery disease, hypercholesterolemia, type 2 diabetes or iron-deficiency anemia. ${ }^{[2-5]}$

In our study, the levels of oxidative stress including total oxidant status, total antioxidant status, and paraoxonase activity in patients with AA were investigated. TOS and TAS levels of the patients were higher than the ones of the control group. However, no significant difference in PONI activities was determined between the patients and healthy subjects, and this status could not be explained. Both TOS and TAS levels of APA were higher than both AFA and AAA. PONI activities of the patients with negative exploration were higher than AFA, ASA and APA. In our study, our data showed that the increase in TOS and TAS levels, and decrease in PONI activities were due to the progression of inflammation to the perforation in acute appendicitis. The increase in both TOS and TAS levels and decrease in PONI activities can be explained by the progression of the inflammation and increased response of the organism to this oxidative stress. The increase of oxidative status (both TOS and TAS) was related with the progression of inflammation to the perforation in acute appendicitis.

Conflict of interest: None declared.

\section{REFERENCES}

1. Hardin DM Jr. Acute appendicitis: review and update. Am Fam Physician 1999;60:2027-34.

2. Bodolay E, Seres I, Szodoray P, Csípo I, Jakab Z, Vegh J, et al. Evaluation of paraoxonase activity in patients with mixed connective tissue disease. J Rheumatol 2008;35:237-43.

3. Furlong CE. Genetic variability in the cytochrome P450-paraoxonase 1 (PON1) pathway for detoxication of organophosphorus compounds. J Biochem Mol Toxicol 2007;21:197-205. CrossRef

4. Chait A, Han CY, Oram JF, Heinecke JW. Thematic review series: The immune system and atherogenesis. Lipoprotein-associated inflammatory proteins: markers or mediators of cardiovascular disease? J Lipid Res 2005;46(3):389-403. CrossRef

5. Erdem FH, Karatay S, Yildirim K, Kiziltunc A. Evaluation of serum paraoxonase and arylesterase activities in ankylosing spondylitis patients. Clinics (Sao Paulo) 2010;65:175-9. CrossRef

6. Koltuksuz U, Uz E, Ozen S, Aydinç M, Karaman A, Akyol O. Plasma superoxide dismutase activity and malondialdehyde level correlate with the extent of acute appendicitis. Pediatr Surg Int 2000;16:559-61. CrossRef

7. Ozdogan M, Devay AO, Gurer A, Ersoy E, Devay SD, Kulacoglu H, et al. Plasma total anti-oxidant capacity correlates inversely with the extent of acute appendicitis: a case control study. World J Emerg Surg 2006;1:6.

8. Kaya M, Boleken ME, Kanmaz T, Erel O, Yucesan S. Total antioxidant capacity in children with acute appendicitis. Eur J Pediatr Surg 2006;16:34-8. CrossRef

9. Yilmaz FM, Yilmaz G, Erol MF, Köklü S, Yücel D. Nitric oxide, lipid peroxidation and total thiol levels in acute appendicitis. J Clin Lab Anal 2010;24:63-6. CrossRef

10. Eckerson HW, Wyte CM, La Du BN. The human serum paraoxonase/ arylesterase polymorphism. Am J Hum Genet 1983;35:1126-38.

11. Erel O. A novel automated direct measurement method for total antioxidant capacity using a new generation, more stable ABTS radical cation. Clin Biochem 2004;37:277-85. CrossRef

12. Erel O. A new automated colorimetric method for measuring total oxidant status. Clin Biochem 2005;38:1103-11. CrossRef

13. Graffeo CS, Counselman FL. Appendicitis. Emerg Med Clin North Am 1996;14:653-71. CrossRef

14. Carr NJ. The pathology of acute appendicitis. Ann Diagn Pathol 2000;4:46-58. CrossRef

15. Butler C. Surgical pathology of acute appendicitis. Hum Pathol 1981;12:870-8. CrossRef

\section{KLINIK ÇALIŞMA - ÖZET}

\section{Akut apandisitte toplam oksitadif durum, toplam antioksidan durum ve paraoksonaz enzim aktivitesi \\ Dr. Hande Köksal, ${ }^{1}$ Dr. Sevil Kurban, ${ }^{2}$ Dr. Osman Doğru ${ }^{1}$}

${ }^{1}$ Konya Eğitim ve Araştırma Hastanesi, Genel Cerrahi Kliniği, Konya;

${ }^{2}$ Necmettin Erbakan Üniversitesi Meram Tıp Fakültesi, Biyokimya Anabilim Dalı, Konya

AMAÇ: Bu çalışmanın amacı, akut apandisit tanısı alan hastalarda toplam okstadif durum, toplam antioksidan durum değerleri ile paraoksonaz enzim aktivitesinin araştıııımasıdır.

GEREÇ VE YÖNTEM: Ameliyat öncesi akut apandisit tanısıyla ameliyata alınan 73 hasta (Grup I) ile kontrol grubu olarak (Grup II) sağ|ıkı 30 kişi çalışmaya alındı. Patolojik inceleme sonucunda hastalar: I) Akut fokal apandisit, 2) Akut ilerlemiş apandisit (süpüratif, flegmenöz ve gangrenöz apandisit), 3) Akut perfore apandisit, 4) Subakut apandisit ve 5) Negatif eksplorasyon olarak sınıflandırıldı. Paraoksonaz enzim aktivitesi, toplam okstadif durum, toplam antioksidan durum değerleri için kan örnekleri ameliyat öncesinde alındı.

BULGULAR: Hastaların toplam oksidatif ve antioksidatif durum düzeyleri kontrol grubuna göre yüksekti. Paraoksonaz enzim aktivitesi karşılaştırıldığında grup I ile II arasında herhangi bir anlamlı fark saptanmadı. Akut perfore apandisitli hastaların toplam oksidatif ve antioksidatif durum düzeyleri hem akut fokal apandisitli hem de akut ilerlemiş apandisitli hastalardan daha yüksek bulundu.

TARTIŞMA: Toplam oksidatif ve antioksidatif durum düzeylerinin akut apandisitli hastalarda enflamasyonun ilerlemesi ile artmaktadır.

Anahtar sözcükler: Akut apandisit; paraoksonaz enzim aktivitesi; toplam antioksidan durum; toplam oksitadif durum.

Ulus Travma Acil Cerrahi Derg 2015;2I(2):139-142 doi: 10.5505/tjtes.2015.03285 